\title{
Clinical and laboratory features of urinary tract infections in young infants
}

\author{
Aspectos clínicos e laboratoriais da infecção do trato urinário em \\ lactentes jovens
}

\section{Authors}

Denise Swei Lo ${ }^{1}$

Larissa Rodrigues ${ }^{1}$

Vera Hermina Kalika Koch ${ }^{2}$

Alfredo Elias Gilio ${ }^{1}$

${ }^{1}$ Universidade de São Paulo,

Hospital Universitário,

Departamento de Pediatria, São

Paulo, SP, Brasil.

2 Universidade de São Paulo, Faculdade de Medicina, Instituto da Criança, Departamento de Pediatria, São Paulo, SP, Brasil.

Submitted on: 05/22/2017. Approved on: 06/25/2017.

\section{Correspondence to:}

Denise Swei Lo.

E-mail: deswlo27@gmail.com

DOI: 10.1590/1678-4685-JBN-3602

\section{Abstract}

Introduction: Urinary tract infection (UTI) is the most common serious bacterial infection in young infants. Signs and symptoms are often nonspecific. Objectives: To describe clinical, demographic and laboratory features of UTI in infants $\leq$ 3 months old. Methods: Cross-sectional study of infants $\leq 3$ months old with UTI diagnosed in a pediatric emergency department, for the period 2010-2012. UTI was defined as $\geq 50,000$ colony-forming units per milliliter of a single uropathogen isolated from bladder catheterization. Paired urinalysis and urine culture from group culture-positive and group culture-negative were used to determine the sensitivity and specificity of pyuria and nitrite tests in detecting UTI. Results: Of 519 urine cultures collected, UTI was diagnosed in 65 cases (prevalence: $12.5 \%$ ); with male predominance $(77 \%)$. The most common etiologies were Escherichia coli (56.9\%), Klebsiella pneumoniae (18.5\%) and Enterococcus faecalis $(7.7 \%)$. Frequent clinical manifestations were fever $(77.8 \%)$, irritability $(41.4 \%)$ and vomiting $(25.4 \%)$. The median temperature was $38.7^{\circ} \mathrm{C}$. The sensitivity of the nitrite test was $30.8 \%$ (95\%CI:19.9-43.4\%), specificity of $100 \%$ (95\% CI:99.2-100\%). Pyuria $\geq 10,000 / \mathrm{mL}$ had a sensitivity of $87.7 \%$ (95\% CI:77.2-94.5\%), specificity of $74.9 \% \quad(95 \% \mathrm{CI}: 70.6 \quad-78.8 \%)$. The median peripheral white blood cell count was $13,150 / \mathrm{mm}^{3}$; C-reactive protein levels were normal in $30.5 \%$ of cases. Conclusions: The male: female ratio for urinary tract infection was 3.3:1. NonEscherichia coli etiologies should be considered in empirical treatment. Fever was the main symptom. Positive nitrite is high-

\section{Resumo}

Introdução: A infecção do trato urinário (ITU) é um quadro infeccioso grave mais frequente em lactentes jovens, cujos sinais e sintomas são frequentemente inespecíficos. Objetivos: Descrever aspectos clínicos, demográficos e laboratoriais de ITU em lactentes $\leq 3$ meses. Métodos: Estudo transversal de ITU diagnosticada em lactentes $\leq 3$ meses, em pronto-socorro geral de pediatria, entre 01/01/2010 a 31/12/2012. Diagnóstico de ITU definida como crescimento $\geq 50.000$ unidades formadoras de colônia por mililitro de uropatógeno único, colhido por cateterismo vesical. Urina tipo I e urocultura foram pareadas dos grupos cultura-positiva e cultura-negativa para determinar a sensibilidade e especificidade de piúria e teste do nitrito para o diagnóstico de ITU. Resultados: Das 519 uroculturas colhidas, confirmou-se 65 casos de ITU (prevalência: $12,5 \%)$, com predomínio em meninos $(77 \%)$. As etiologias mais frequentes foram Escherichia coli (56,9\%), Klebsiella pneumoniae $(18,5 \%)$ e Enterococcus faecalis $(7,7 \%)$. Os sintomas mais frequentes foram febre $(77,8 \%)$, irritabilidade $(41,4 \%)$ e vômitos $(25,4 \%)$. A temperatura mediana foi de $38,7^{\circ} \mathrm{C}$. A sensibilidade do nitrito positivo foi de 30,8\% (IC95\%:19,9-43,4\%), especificidade de 100\% (IC95\%:99,2-100\%). Piúria $\geq 10.000 / \mathrm{mL}$ apresentou sensibilidade de $87,7 \%$ (IC95\%:77,2-94,5\%), especificidade de 74,9\% (IC95\%:70,6-78,8\%). A contagem mediana de leucócitos foi $13.150 / \mathrm{mm}^{3}$. A proteína C reativa foi normal em 30,5\% dos casos. Conclusões: A proporção entre meninos e meninas para ITU foi de 3,3:1. Outros agentes além de Escherichia coli devem ser considerados no tratamento empírico. A febre foi a principal queixa. O nitrito positivo é alta- 
ly suggestive of UTI but has low sensitivity; whereas pyuria $\geq 10,000 / \mathrm{mL}$ revealed good sensitivity, but low specificity. Peripheral white blood cell count and Creactive protein concentration have limited usefulness to suggest UTI.

Keywords: urinary tract infections; urinalysis; Escherichia coli; C-Reactive protein; pyuria; leukocyte count. mente sugestivo de ITU mas tem baixa sensibilidade; enquanto que a piúria $\geq 10.000 / \mathrm{mL}$ revelou boa sensibilidade, porém baixa especificidade. Leucograma e proteína $\mathrm{C}$ reativa demonstraram pouca utilidade clínica para sugerir ITU.

Palavras-chave: infecções urinárias; urinálise; Escherichia coli; proteína $\mathrm{C}$ reativa; piúria; contagem de leucócitos.

\section{INTRODUCTION}

Urinary tract infection (UTI) has been described as the most frequent severe bacterial infection in infants below the age of three months. ${ }^{1-4} \mathrm{~A}$ meta-analysis by Shaikh $\mathrm{N}$ et al. ${ }^{5}$ showed that the prevalence of UTI in young infants with fever was $7.5 \%$ in girls and ranged from $2.4 \%$ in circumcised boys to $20.1 \%$ in non-circumcised boys. The major challenge is that signs and symptoms at this age tend to be nonspecific. ${ }^{3,6}$ As has been reported, fever is the main symptom, followed by irritability, lethargy, vomiting, diarrhea, anorexia, jaundice and low weight gain. ${ }^{3,6,7}$

Young infants are at a higher risk for developing pyelonephritis, especially if the diagnosis and adequate antimicrobial therapy are delayed. ${ }^{6,8-11}$ There is an association between delayed therapy of febrile UTI and an increased risk of progression resulting in renal scarring. ${ }^{11,12}$ Such cases tend to progress to hypertension and renal failure. ${ }^{13}$ Young infants, whose immune systems is still maturing, are particularly vulnerable to bacteremia associated with pyelonephritis. ${ }^{14}$ The definitive diagnosis of UTI is based on finding significant bacteriuria in a quantitative urine culture, which may takes days to yield a final result. Thus, empirical therapy should be initiated if UTI is suspected in clinical data and laboratory tests such as urinalysis and/or bacterioscopy of urine. Other tests often carried out to assess the risk of bacterial infection in febrile infants, such as the white blood cell count and the reactive C-reactive protein (CRP) test are of questionable value for a presumptive diagnosis of pyelonephritis. Studies in young infants, however, are lacking. ${ }^{15,16}$ Furthermore, the American Academy of Pediatrics has excluded infants aged below 2 months in its recommendations for the therapy of UTI. ${ }^{17,18}$

This epidemiological review aims to describe the clinical and laboratory findings of UTI in infants aged below 3 months in an urban community. The diagnosis of this condition is enhanced by understanding the prevalence of UTI and the main clinical and laboratory findings in urine and blood tests at this age group. A description of the main causative agents and the antimicrobial susceptibility profile may help chose the best therapy in our context.

\section{Method}

\section{TYPE OF STUDY AND CONTEXT}

An epidemiological cross-sectional cohort study was conducted at the University Hospital of University of Sao Paulo, a secondary level hospital that serves a population of about 500 thousand people in the Western region of São Paulo. The study site was the Pediatrics Emergency Unit. The study was undertaken from $1^{\text {st }}$ January 2010 to $31^{\text {st }}$ December 2012; during this period, 188,440 cases of children aged $0-15$ years were seen.

\section{LABORATORY METHODS AND DEFINITION OF UTI}

Urine samples were collected by urinary bladder catheterization. Antisepsis was carried out with $1 \%$ aqueous. Urine samples were immediately sent to the hospital laboratory; urine cultures were plated onto blood agar medium and MacConkey agar (Plastlabor ${ }^{\circledR}$, Rio de Janeiro). The Vitek (Bio-Mérieux ${ }^{\circledR}$ ) was used to identify and test the susceptibility of strains. UTI was established when a quantitative urine culture of urine collected by urinary bladder catheterization yielded growth of $\geq 50,000$ colony forming units $(\mathrm{CFU}) / \mathrm{mL}$ of a single microbial agent.

Urine nitrite was tested in urinalysis samples for positivity using reagent strips (Multistix ${ }^{\circledR} 10$ SG - Siemens) in semiautomatic equipment (Clinitek Advantus - Siemens), based on the light reflectance spectrophotometry. Urine sediment microscopy of centrifuged urine was done with a common optical 
microscope at $10 \mathrm{x}$ and $40 \mathrm{x}$ magnification; white blood cells were observed and quantified by using a Neubauer chamber.

\section{STUDY POPULATION AND METHOD}

All infants aged from 0 to 3 months that sought the emergency unit and underwent urine culture tests were enrolled, on medical criteria. Demography data (sex and age), clinical and laboratory findings of infants with confirmed UTI were investigated. Signs and symptoms in order of frequency were: fever, maximum verified temperature, irritability, vomiting, inadequate food intake, dehydration, low weight gain, jaundice, constipation, diarrhea and altered urine. These were itemized as percentages over the total number of recordings found in patient registries. Laboratory data consisted of: urinalysis (quantifying urinary white blood cells and a positive nitrite test), a red blood count and a C-reactive protein (CRP). The white blood cell count and CRP were described as the median, minimal and maximal values. Microorganisms found in quantitative urine cultures were expressed as number of episodes and percentages. All episodes of UTI caused by urine micropathogens were added and assessed regarding susceptibility to commonly used antimicrobial agents.

Urinalysis test results in young infants without UTI during the study period were used for comparison purposes with the positive UTI group. The chi-square test and Fisher's exact test were used for comparing the groups. The sensitivity, specificity, positive predictive value (PPV) and the negative predictive value (NPV) of a cutoff point for white blood cells (WBC) of $\geq 10,000 \mathrm{WBC} / \mathrm{mL}$ in urinalysis and a positive nitrite test were evaluated as criteria for diagnosing UTI. These parameters were expressed in $95 \%$ confidence intervals (CI 95\%). Exclusion criteria were: incomplete identification or laboratory data in patient registries and test sampling of the same patient twice on the same day.

\section{ETHICS}

The research ethics committee of the Hospital approved this epidemiological study (registry number $622 / 05)$.

\section{RESULtS}

Figure 1 presents the series during the 3-year study period. A total of 534 urine cultures of 501 infants aged less than 3 years with suspected UTI were done. In this group, one urine culture was carried out in each of 470 infants, two urine cultures were done in each of 29 infants, and three urines cultures were done in each of 2 infants. Incomplete patient identification and/or laboratory data led to 15 patients being excluded from the study. OF 519 episodes that were investigated, 454 urine cultures were negative, and 65 urine cultures were positive. Thus, the full number of cases of UTI in our statistical analysis was 65, in 64 infants. One male patient had two UTI episodes caused by $E$. coli with a 19-day interval between each episode.

Figure 1. Flowchart of the cohort.

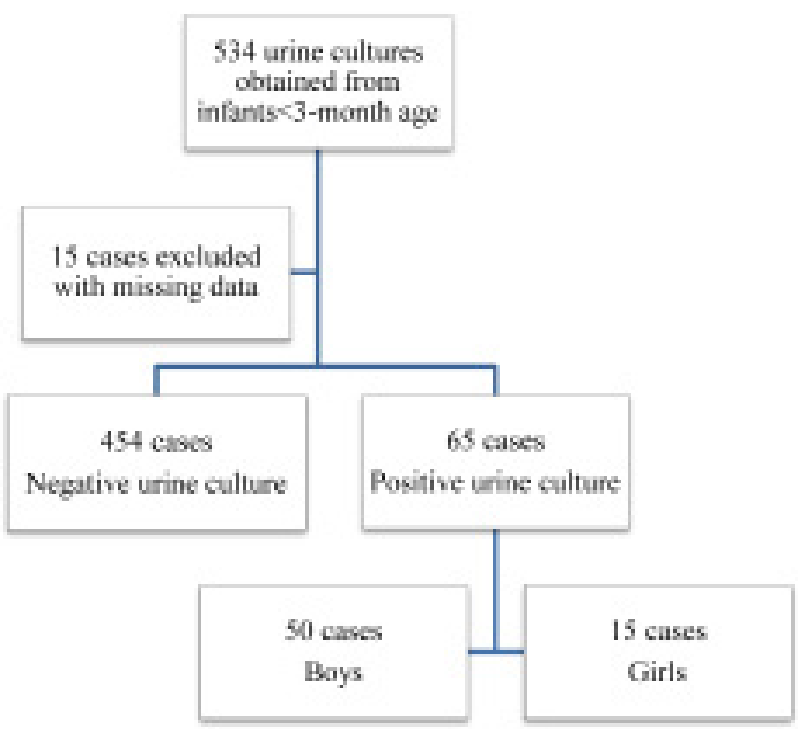

The prevalence of UTI was $12.5 \%$. The male to female ratio was 3.3: 1. Table 1 presents the clinical and laboratory findings of infants with UTI, aged below 3 years. The median temperature of fever was $38.7^{\circ} \mathrm{C}$; $64.9 \%$ subjects had temperatures below $39^{\circ} \mathrm{C}$. Supplementary tests were the complete blood count (done in 60 cases), in which the median value of WBC was within normal limits $\left(13,150 / \mathrm{mm}^{3}\right)$. The C-reactive protein (CRP) test was done in 36 cases and was within normal limits in $30.5 \%$ of samples. Urinalysis was done in all 65 cases. Comparing the 
positive UTI and negative UTI groups with the chisquare test showed that a cutoff point of white blood cells (WBC) in urine of more than $10,000 \mathrm{WBC} / \mathrm{mL}$ had a sensitivity of $87.7 \%$ (CI $95 \%: 77.2 \%-94.5 \%$ ), a specificity of $76.6 \%$ (CI 95\%: $72.5 \%-80.5 \%$ ), a positive predictive value (PPV) of $35.0 \%$ (CI 95\%: $27.7 \%-42.8 \%$ ), and a negative predictive value (NPV) of $97.7 \%$ (CI 95\%: 95.6\%-99.0\%). This comparison applied to a positive nitrite test showed a sensitivity of $30.8 \%$ (CI $95 \%$ : $19.9 \%-43.4 \%$ ), a specificity of $100 \%$ (CI 95\%: $99.2 \%-100 \%$ ), a PPV of $100 \%$ (CI $95 \%$ : $83.2 \%-100 \%$ ), and a NPV of $91.0 \%$ (CI 95\%: $88.1 \%-93.3 \%)$. There were no cases of bacteremia due to UTI in the 63 cases in whom blood cultures were carried out.

\begin{tabular}{|c|c|c|}
\hline TABLE 1 & \multicolumn{2}{|c|}{$\begin{array}{l}\text { CLINICAL AND LABORATORY FINDINGS OF } \\
\text { INFANTS AGED BELOW } 3 \text { MONTHS WITH } \\
\text { URINARY TRACT INFECTION }\end{array}$} \\
\hline \multicolumn{3}{|l|}{ Variable } \\
\hline Male se & & $50(76.9 \%)$ \\
\hline \multicolumn{2}{|c|}{ Age in months $\pm S D$, median } & $1.5 \pm 0.7$ \\
\hline \multicolumn{2}{|c|}{ Maximum fever temperature } & $39.5^{\circ} \mathrm{C}$ \\
\hline \multicolumn{2}{|c|}{ Median temperature \pm SD } & $38.7^{\circ} \mathrm{C} \pm 0.5^{\circ} \mathrm{C}$ \\
\hline \multicolumn{2}{|c|}{ White blood cells $/ \mathrm{mm}^{3} \pm \mathrm{SD}$} & $13150 \pm 5852$ \\
\hline \multicolumn{2}{|c|}{$\begin{array}{l}\text { Blood counts with white blood cells } \\
\geq 15,000 / \mathrm{mm}^{3}\end{array}$} & $33.30 \%$ \\
\hline \multicolumn{2}{|c|}{$\mathrm{CRP}(\mathrm{mg} / \mathrm{L})$, median } & 17.5 \\
\hline \multicolumn{2}{|c|}{$\mathrm{CRP}<5 \mathrm{mg} / \mathrm{L}$} & $30.5 \%$ \\
\hline \multicolumn{2}{|c|}{ Urinary white blood cells $>10,000 / \mathrm{mL}$} & $57(87.7 \%)$ \\
\hline \multicolumn{2}{|c|}{ Positive nitrite } & $20(30.8 \%)$ \\
\hline
\end{tabular}

SD: standard deviation; CRP: C-reactive protein

Signs and symptoms are shown in Table 2. Percentages were calculated over the full number of registries of each datum. Information retrieval was possible in 89.2 to $96.9 \%$ of patient registries. The main symptom was fever without locating signs, which was found in $77.8 \%$ of cases; it was followed by irritability $(41.4 \%)$ and vomiting $(25.4 \%)$. Parents or caretakers reported changes in urine in only $10.3 \%$ of cases. No cases presented with jaundice.

Table 3 presents the causative microbial agents that were found in our cohort. The most frequent agent was E. coli, found in $56.9 \%$ of cases, followed by Klebsiella pneumoniae (18.5\%) and Enterococcus faecalis $(7.7 \%)$. Of 5 UTI cases due to E. faecalis (infants aged 8,11, 19, 27 and 50 days), 4 were newborn. The sensitivity of these microbial agents was higher

\begin{tabular}{lcc} 
TABLE 2 & $\begin{array}{c}\text { SIGN AND SYMPTOMS OF INFANTS AGED } \\
\text { BELOW } 3 \text { MONTHS WITH URINARY TRACT } \\
\text { INFECTION }\end{array}$ \\
\hline Signs and symptoms & $\begin{array}{l}\text { No. of cases/ } \\
\text { No. registries }\end{array}$ & $\%$ \\
\hline Fever without localizing signs & $49 / 63$ & 77.8 \\
Irritability & $24 / 58$ & 41.4 \\
Vomiting & $15 / 59$ & 25.4 \\
Low food intake & $12 / 58$ & 20.7 \\
Clinical dehydration & $11 / 58$ & 19.0 \\
Low weight gain & $8 / 58$ & 13.8 \\
Constipation & $7 / 58$ & 12.1 \\
Diarrhea & $4 / 58$ & 6.9 \\
Urinary changes & $6 / 58$ & 10.3 \\
\hline
\end{tabular}

than or equal to $80 \%$ to the following antimicrobials: aminoglycosides (gentamycin: $80 \%$, amikacin: $86.2 \%$ ), third-generation cephalosporins (cefotaxime: $84.6 \%$, ceftazidime: $89.2 \%$ ), fourth-generation cephalosporins (cefepime: $87.7 \%$ ). E. faecalis were all sensitive to ampicillin. A few urinary pathogens had low sensitivity to commonly used antimicrobial agents in the empirical treatment of UTI in older children, such as: first-generation cephalosporin (cephalothin: $63.1 \%)$, sulfamethoxazole-trimethoprim $(60 \%)$, and amoxicillin-clavulanate $(73.8 \%)$.

\begin{tabular}{lcc} 
TABLE 3 & $\begin{array}{c}\text { ETIOLOGICAL AGENTS IN INFANTS AGED } \\
\text { BELOW 3 MONTHS WITH URINARY TRACT } \\
\text { INFECTION }\end{array}$ \\
\hline Etiological agents & $\mathrm{n}$ & $\%$ \\
\hline Escherichia coli & 37 & 56.9 \\
Klebsiella pneumoniae & 12 & 18.5 \\
Enterococcus faecalis & 5 & 7.7 \\
Enterobacter aerogenes & 3 & 4.7 \\
Proteus mirabilis & 2 & 3.1 \\
Enterobacter cloacae & 2 & 3.1 \\
Staphylococcus epidermidis & 1 & 1.5 \\
Raoultella planticola & 1 & 1.5 \\
Serratia marcescens & 1 & 1.5 \\
Pantoea spp & 1 & 1.5 \\
Total & 65 & 100 \\
\hline
\end{tabular}

\section{Discussion}

This study aims to bring clinical and laboratory knowledge about UTI in infants aged below 3 months in an urban community. Among this cohort, we found a high prevalence of UTI $(12.5 \%)$ 
over the total number of urine cultures done in this group. There were three times more cases among females, concurring with previous studies. ${ }^{1,6,9,10,19,20}$ Fever without localizing signs was the main presenting sign $(77.8 \%$ of cases). As in previous papers, ${ }^{15,21}$ the complete blood count and the CRP were of little clinical use in the diagnosis of UTI; the white blood counts were within normal limits, and $30.5 \%$ of CRP tests were within normal. The median CRP test value was lower than $20 \mathrm{mg} / \mathrm{L}$, a number that has been used by some authors to suggest a diagnosis of pyelonephritis. ${ }^{15,21}$ In the urinalysis, a positive nitrite test was highly specific and had a high PPV; therefore, if initial screening reveals a positive nitrite test, antimicrobial agents should be started immediately after collecting samples for quantitative urine cultures. The nitrite test, however, had low sensitivity and should not be used to discard UTI. On the other hand, a white blood cell (WBC) cutoff value of $\geq 10,000 / \mathrm{mL}$ (equal to $10 \mathrm{WBC} / \mathrm{mm}^{3}$ ) was reasonably sensitive for a presumptive diagnosis of UTI; its specificity and PPV, however, were low. ${ }^{21,22}$ In our cohort, starting empirical therapy using a white blood cell count of $\geq 10,000 / \mathrm{mL}$ as a cutoff point would results in unnecessary treatment of $65.0 \%$ of cases.

UTI should not be suspected base on urinary complaints, which were present in only $10.3 \%$ of our cohort, or on high fever, which was often below $39^{\circ} \mathrm{C}$ in $64.9 \%$ of our cohort. Our findings agree with previous papers that report fever as the main symptom in young infants with non-specific clinical findings. ${ }^{1,3,6,7}$ No patient presented with jaundice in our cohort; it has been reported previously. ${ }^{7,23}$ In this age group, some authors have defined UTI as present when there are more than $50,000 \mathrm{CFU} / \mathrm{mL}$ of a single pathogen, or $\geq 10,000$ $\mathrm{CFU} / \mathrm{mL}$ together with changes in urinalysis., ${ }^{3,24}$ The American Academy of Pediatrics included an association between a qualitative urine culture with over $50,000 \mathrm{CFU} / \mathrm{mL}$ and urinary bacteria and/or white blood cells in urine as a criterion for diagnosing UTI in the 2 to 24 month age group. ${ }^{18,19}$ In our cohort, 8 cases $(12.3 \%)$ had urinary white blood cell counts below $10,000 / \mathrm{mL}$ and a negative nitrite test, but with quantitative urine culture showing over $50,000 \mathrm{CFU} / \mathrm{mL}$ of a single type of bacteria. In all of these cases, urine samples were collected based on clinical findings (fever, irritability, vomiting, anorexia, low weight gain, dehydration or urinary changes); these cases should not be classified as asymptomatic bacteriuria. Therefore, it is important to carry out urinalysis and urine cultures sampled by bladder catheterization in young infants. This recommendation concurs with the findings in Shaikh et al.'s ${ }^{25}$ paper, which reported that about $10 \%$ of children had urinary symptoms and confirmed UTI by urine cultures even though the white blood cell count in urinalysis was within normal limits. This is seen more frequently in UTI cases caused by Enterococcus, Klebsiella and P. aeruginosa species, all of which are relevant in young infants. On the other hand, if the urinary white blood cell count was $\geq 10,000 / \mathrm{mL}$ in urinalysis, a negative urine culture was important to eventually interrupt antimicrobial therapy.

E. coli was the main microorganism in our cohort $-56.9 \%$ of cases. This prevalence was lower than previously published results in this age group $(62 \%-88 \%),{ }^{1,4,6,9,10,17}$ but higher than the $41.7 \%$ prevalence reported by Chen et al. ${ }^{23}$ in young infants with elevated blood bilirubin secondary to UTI. Other microorganisms that should be considered when initiating empirical antimicrobial therapy are: K. pneumoniae $(18.5 \%)$ and E. faecalis $(7.7 \%)$. The choice of empirical antimicrobial therapy should take into account updated information about the prevalence of urinary pathogens for each age, sex and place. ${ }^{17}$ According to the sensitivity profiles of such urinary pathogens, it is appropriate to start empirical therapy with an aminoglycoside (amikacin) or a third-generation cephalosporin, associated with ampicillin if there are Gram-positive cocci (E. faecalis), especially in neonates.

The purpose of this study was to assess the presenting clinical and laboratory findings of young infants, not including the progression of therapy and laboratory testing. It is relevant to consider that UTI may be the first sign that a child has a congenital anomaly of the kidney or urinary tract. ${ }^{6,8,10}$ Given the retrospective nature of this study, we were unable to accurately characterize imaging methods in the evaluation of anatomical changes 
of the urinary tract in our cohort. We also had no access to prenatal ultrasounds of these infants to check for any diagnosis of renal and urinary malformations. Urine bacterioscopy, which could have been useful in the initial approach of these cases while waiting for quantitative urine cultures, was not carried out in our study. ${ }^{18,19}$ We were unable to accurately gather specific types of clinical data, such as recent use of antimicrobial medication, which could have altered the causative agent and antimicrobial sensitivity. ${ }^{26}$ Our series consisted of previously healthy infants brought spontaneously to a secondary level hospital by caretakers. We therefore consider this group to be representative of an etiological profile in an urban community of the city of São Paulo. Brazilians comprise a mixture of races, so that we were unable to establish if the prevalence of UTI is higher among Whites. ${ }^{5}$ We were also unable to define whether postectomy had any protecting effect against UTI in males, as previously reported. ${ }^{5}$ As this is not a common procedure in our community, it is likely that the prevalence of postectomy among males in our community is negligible.

In spite of the limitations of retrospective studies, our paper raises an alert about the need to investigate UTI with quantitative urine cultures in young infants that present with non-specific symptoms, and not to discard this diagnosis when a white blood cell count and/or CRP tests are within normal limits. Although E. coli was the main microbial agent, other Gram-negative microorganisms, such as K. pneumoniae, and Gram-positive cocci, such as E. faecalis. should be considered in the empirical approach to this condition. For additional knowledge about UTI in young infants, additional prospective studies are important to overcome the limiting factors described above, to assess urinary tract morphology in these cases, to evaluate the response to antimicrobial therapy and to observe further developments.

\section{References}

1. Bonadio W, Maida G. Urinary tract infection in outpatient febrile infants younger than 30 days of age: a 10 -year evaluation. Pediatr Infect Dis J. 2014; 33(4):342-4.

2. Bachur RG, Harper MB. Predictive model for serious bacterial infections among infants younger than 3 months of age. Pediatrics. 2001;108(2):311-6.

3. Simões e Silva AC, Oliveira EA. Update on the approach of urinary tract infection in childhood. J Pediatr (Rio J). 2015;91:S210 .
4. Greenhow TL, Hung Y-Y, Herz AM, Losada E, Pantell RH. The changing epidemiology of serious bacterial infections in young infants. Pediatr Infect Dis J. 2014;33(6):595-9.

5. Shaikh N, Morone NE, Bost JE, Farrell MH. Prevalence of urinary tract infection in childhood: a meta-analysis. Pediatr Infect Dis J. 2008;27(4):302-8.

6. Sastre JBL, Aparicio AR, Cotallo GD, Colomer BF, Hernández MC, Grupo de Hospitales Castrillo. Urinary tract infection in the newborn: clinical and radio imaging studies. Pediatr Nephrol. 2007;22:1735-41.

7. Garcia FJ, Nager AL. Jaundice as an early diagnostic sign of urinary tract infection in infancy. Pediatrics. 2002;109(5):84651.

8. Goldman M, Lahat E, Strauss S, Reisler G, Livne A, Gordin $\mathrm{L}$, et al. Imaging after urinary tract infection in male neonates. Pediatrics. 2000;105(6):1232-5.

9. Ismaili K, Lolin K, Damry N, Alexander M, Lepage P, Hall M. Febrile urinary tract infections in 0- to 3-month-old infants: A prospective follow-up study. J Pediatr. 2011;158(1):91-4.

10. Lee JH, Lim H, Kim K, Yim HE, Yoo KH. Are the Clinical outcomes of Neonates and Infants Under 2 Months Old with Urinary Tract Infections Similar to those in Infants 2 to 12 Months Old? Child Kidney Dis. 2015;19(2):136-42.

11. Shaikh N, Mattoo TK, Keren R, Ivanova A, Cui G, MoxeyMims M, et al. Early Antibiotic Treatment for Pediatric Febrile Urinary Tract Infection and Renal Scarring. JAMA Pediatr. 2016;170(9):848-54.

12. Coulthard MG, Lambert HJ, Vernon SJ, Hunter EW, Keir MJ, Matthews JNS. Does prompt treatment of urinary tract infection in preschool children prevent renal scarring: mixed retrospective and prospective audits. Arch Dis Child. 2014;99(4):342-7.

13. Jacobson SH, Eklöf O, Eriksson CG, Lins LE, Tidgren B, Winberg J. Development of hypertension and uraemia after pyelonephritis in childhood: 27 year follow up. BMJ. 1989;299:703-6.

14. Bachur R, Caputo GL. Bacteremia and meningitis among infants with urinary tract infections. Pediatr Emerg Care 1995;11(5):280-4.

15. Shaikh N, Borrell JL, Evron J, Leeflang MMG. Procalcitonin, C-reactive protein, and erythrocyte sedimentation rate for the diagnosis of acute pyelonephritis in children. Cochrane database Syst Rev. 2015;1:CD009185.

16. Shaikh N, Craig JC, Rovers MM, Da Dalt L, Gardikis S, Hoberman A, et al. Identification of Children and Adolescents at Risk for Renal Scarring After a First Urinary Tract Infection: A Meta-analysis With Individual Patient Data. JAMA Pediatr. 2014;168(10):893-900.

17. Subcommittee on Urinary Tract Infection, Steering Committee on Quality Improvement and Management. Roberts KB. Urinary tract infection: clinical practice guideline for the diagnosis and management of the initial UTI in febrile infants and children 2 to 24 months. Pediatrics. 2011;128(3):595610.

18. Subcommittee on Urinary Tract Infection. Reaffirmation of AAP Clinical Practice Guideline: The Diagnosis and Management of the Initial Urinary Tract Infection in Febrile Infants and Young Children 2-24 Months of Age. Pediatrics. 2016;138(6):e20163026

19. Lo DS, Shieh HH, Ragazzi SLB, Koch VHK, Martinez $\mathrm{MB}$, Gilio AE. Community-acquired urinary tract infection: age and gender-dependent etiology. J Bras Nefrol. 2013;35(2):93-8.

20. Ladomenou F, Bitsori M, Galanakis E. Incidence and morbidity of urinary tract infection in a prospective cohort of children. Acta Paediatr. 2015;104(7):e324-9.

21. Lin DS, Huang SH, Lin CC, Tung YC, Huang TT, Chiu NC, et al. Urinary tract infection in febrile infants younger than eight weeks of Age. Pediatrics. 2000;105(2):e2.

22. Glissmeyer Eric W, Sheng P, Blaschke AJ, Kent Korgenski E, Wilkes J, Schunk JE, et al. Dipstick Screening for Urinary Tract Infection in Febrile Infants. Pediatrics. 2014;133(5):e1121. 
23. Chen HT, Jeng MJ, Soong WJ, Yang CF, Tsao PC, Lee YS, et al. Hyperbilirubinemia with urinary tract infection in infants younger than eight weeks old. J Chinese Med Assoc. 2011;74(4):159-63.

24. Schnadower D, Kuppermann N, Macias CG, Freedman SB, Baskin MN, Ishimine P, et al. Febrile infants with urinary tract infections at very low risk for adverse events and bacteremia. Pediatrics. 2010;126(6):1074-83.
25. Shaikh N, Shope TR, Hoberman A, Vigliotti A, Kurs-Lasky M, Martin JM. Association Between Uropathogen and Pyuria. Pediatrics. 2016; 138(1):e20160087

26. Bryce A, Hay AD, Lane IF, Thornton H V, Wootton M, Costelloe C. Global prevalence of antibiotic resistance in paediatric urinary tract infections caused by Escherichia coli and association with routine use of antibiotics in primary care: systematic review and meta-analysis. BMJ. 2016;352:1939.

\section{ERRATUM}

In the article "Clinical and laboratory features of urinary tract infections in young infants", with DOI code number http://dx.doi.org/10.1590/1678-4685-jbn-3602, published at Brazilian Journal of Nephrology, 40(1): 66-72, on the page 70 :

Where it was written:

\section{Discussion}

This study aims to bring clinical and laboratory knowledge about UTI in infants aged below 3 months in an urban community. Among this cohort, we found a high prevalence of UTI (12.5\%) over the total number of urine cultures done in this group. There were three times more cases among females, concurring with previous studies.

Should read:

\section{Discussion}

This study aims to bring clinical and laboratory knowledge about UTI in infants aged below 3 months in an urban community. Among this cohort, we found a high prevalence of UTI $(12.5 \%)$ over the total number of urine cultures done in this group. There were three times more cases among males, concurring with previous studies. 